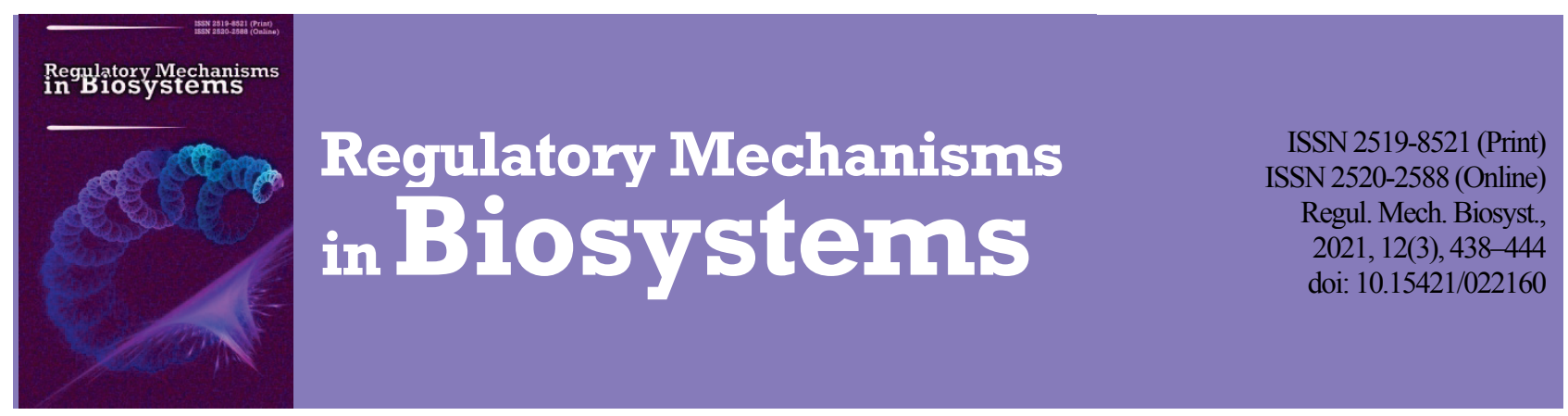

\title{
Efficacy of using a complex of minerals and vitamins for prevention of complications in bone tissue and the digestive tract in rats with hypothyroidism
}

\author{
O. A. Makarenko, O. V. Zaderei, H. V. Maikova \\ Odessa I. I. Mechnikov National University, Odessa, Ukraine
}

\section{Article info \\ Received 04.07.2021 \\ Received in revised form 01.08 .2021 \\ Accepted 02.08.2021}

Odessa I. I. Mechnikov

National University,

Champagne Alley, 2

Odessa, 65058,

Ukraine.

Tel.: +38-098-276-00-03.

E-mail:

aleksandrasakaluk@

gmail.com

\author{
Makarenko, O. A., Zaderei, O. V., \& Maikova, H. V. (2021). Efficacy of using a complex of minerals and vitamins for prevention of \\ complications in bone tissue and the digestive tract in rats with hypothyroidism. Regulatory Mechanisms in Biosystems, $12(3), 438-444$. \\ doi:10.15421/022160
}

Significant consequences of hypothyroidism are impairments in all types of metabolism, including bone metabolism, pathological changes in the digestive tract and the development of deficiency of vitamins, macro-and micronutrients. The relevance of the study is due to the widespread occurrence of hypothyroidism and the feasibility of developing effective methods for the prevention of the pathology and its complications. The study was aimed at the condition of bone tissue and digestive tract in rats with hypothyroidism, as well as the effectiveness of preventive addition of a complex of vitamins and minerals. The studies were performed on rats with hypothyroidism that was caused using thyrostatic mercazolyl for 50 days, administered orally. Prophylaxis was performed by adding a prophylactic complex of vitamins $\mathrm{P}$, $\mathrm{C}, \mathrm{D}$ and minerals $\mathrm{Ca}, \mathrm{Mg}, \mathrm{Cu}, \mathrm{Se}, \mathrm{Mn}$ to the daily diet. In the bone tissue of rats, the indicators of destruction (elastase and acid phosphatase activity) and mineralization (alkaline phosphatase activity, calcium content) as well as the antioxidant state (activities of catalase, glutathione reductase, malonic dialdehyde content) were studied. In the gums and mucous membranes of the digestive tract of rats, we determined indicators of antioxidant status (catalase activity, malonic dialdehydecontent), inflammation (activities of elastase, acid phosphatase) and dysbiosis (activities of urease activity, lysozyme). In the bone tissue of rats with hypothyroidism, activation of destruction processes, reduction of calcium levels, activation of lipid peroxidation and antioxidant enzymes were found. Hypothyroidism also led to pathological disorders in the gums of rats and gastric mucosa, small and large intestine, namely - the development of inflammation, increased membrane permeability, activation of lipid peroxidation, increased contamination with opportunistic bacteria against the background of reduced antioxidant protection. In general, preventive use of the complex contributed to the normalization of the studied parameters in the gums, mucous membranes of the stomach, intestines, as well as remodeling processes and antioxidant-prooxidative state in the bone tissue of animals with hypothyroidism. In the conditions of hypothyroidism, the proposed complex of vitamins and minerals provided notable antioxidant, anti-inflammatory and antidysbiotic effects in the tissues of the gastrointestinal tract, thus overcoming the calcium deficiency in the blood and stopping the destructive and oxidative processes in the bone tissue of animals with hypothyroidism.

Keywords: thyroid gland; oxidative stress; antioxidant system; alveolar processes, digestive system.

\section{Introduction}

Thyroid disorders are quite common among the population, which leads to increased attention to this problem. The relevance of the issue increases due to the fact that the problems of thyropathology are exacerbated by the fact that against the background of thyroid disorders there are changes in the functioning not only of the humoral system, but also in the whole body (Vernyhorodskyi et al., 2011; Hyrla, 2014).

It is known that thyroid dysfunction affects calcium-phosphorus metabolism and bone metabolism. The processes of bone remodeling was confirmed to have decreased in patients with hypothyroidism by 2-3 times (Engler et al., 1999; Ametov \& Doskina, 2004). Therefore, a comprehensive study of the state of mineral metabolism and antioxidant system in the presence of thyroid dysfunction is relevant and important for the development of more effective measures of diagnosis and correction.

In previous studies, we found that experimental hypothyroidism caused by mercazolyl leads to an increase in the organ index of the thyroid gland and changes in bone mineral density of the femur and lumbar vertebrae by reducing the proportion of protein component and increasing its mineralization (Makarenko \& Zaderei, 2020). Our results are confirmed by the researches of authors who determined 2-3-fold decrease in processes of bone remodeling in the patients with a hypothyroidism (Engler et al., 1999, Ametov \& Doskina, 2004) and also thickening of the surface layer of an ileal bone, consolidation of an arch of the skull base spongy substance in patients with hypothyroidism (Nochevnaya, 2011). The analysis of scientific sources suggests that most patients with hypothyroidism have deficiency in vitamins, macro-and micronutrients (Tereshchenko, 2000). The important role of these essential compounds as parts of the general homeostatic system in the regulation of all body systems is well known. In this regard, there is a need to substantiate and develop the prevention of disorders of bone metabolism in hypothyroidism by using a complex of macro-and micronutrients. Due to the theoretical substantiation of such a prophylactic complex, we have chosen calcium, magnesium, quercetin (vitamin P), vitamins D, C, trace elements selenium, copper, and manganese.

First of all, the essential macronutrients that are directly involved in the regulation of bone metabolism include calcium and magnesium, which provide the body with the processes of bone formation, tooth enamel, and are involved in more than 300 biological reactions. As known, magnesium deficiency leads to decrease in thyroid function (hypothyroidism) due to the synergistic function of the parathyroid gland, which regulates the absorption of magnesium. Magnesium stimulates the thyroid gland to produce thyroxine, and is directly involved in the conversion of thyroxine to triiodothyronine. Magnesium also plays an important role in iodine uptake by the thyroid gland (Jones et al., 1966; Yanko, 2018).

Not only iodine deficiency but also selenium plays a significant role in the development of hypothyroidism. In the 1960s, it was found that selenium, as an antioxidant, is involved in the destruction of hydroperoxi- 
des and lipid peroxides, protecting the body from oxidative stress (Tutelyan et al., 2002). It is known that selenium is a component of iodothyronidefodinase - an enzyme responsible for the peripheral conversion of thyroxine in the liver and kidneys, so its deficiency is accompanied by lack of enzyme and, consequently, incomplete iodine metabolism (Rustembekova et al., 2008; Pankiv, 2014).

As a component of many enzymes and cofactor, manganese plays an important role in a number of physiological processes in mammals. In the absence of manganese, ossification processes are disrupted throughout the skeleton, tubular bones thicken and shorten, joints become deformed. Manganese-containing enzyme superoxide dismutase (Mn-SOD) is the main antioxidant enzyme that neutralizes the toxic effects of reactive oxygen species (Soldin \& Aschner, 2007). The role of SOD in the thyroid gland includes not only the protection of cells against radicals, but also participation in the production of $\mathrm{H}_{2} \mathrm{O}_{2}$ as a substrate for thyroid peroxidase (Verma et al., 1991). There is a number of studies on changes in MnSOD activity (Ono et al., 1991).

Copper is an essential trace element of the body's antioxidant defenses. The physiological role of copper is associated with its participation in a number of enzymes: peroxide dismutase and tyrosinase, which are involved in the production of melanin; dopamine-beta-hydroxylase, on which the production of catecholamines depends. Its deficiency affects the endocrine system, including the thyroid gland. At the same time, there is a decrease in this element in the serum of patients with hypothyroidism, which can lead to disruption of redox processes in the body. Therefore, it is advisable to use this element as a component of the prophylactic complex of patients with thyroid dysfunction.

Vitamin D deficiency correlates with decreased thyroid function and the severity of hypothyroidism, determining the need for additional administration of vitamin D by all patients with an autoimmune pathology. It was found that $25(\mathrm{OH}) \mathrm{D}$ has a significantly strong negative correlation with antibodies to thyroperoxidase and thyroid-stimulating hormone levels, a medium positive correlation with thyroxine and triiodothyronine levels (Tamer et al., 2011; Mackawy et al., 2013; Chukur \& Pasechko, 2020).

Ascorbic acid is one of the regulators of redox reactions and has a pronounced reducing ability. There are significant changes in the prooxidant-antioxidant balance in patients with hypothyroidism. This is manifested by an increase in free radical oxidation processes and a decrease in antioxidant defense systems. Pathological effects occur with excessive accumulation of reactive oxygen species, peroxides and their by-products - a condition commonly called oxidative stress (Naidu, 2003; Blomhoff, 2005; Timirkhanova, 2007). Ascorbic acid is a cofactor of hydroxylases, involved in the catabolism of thyroxine, the biosynthesis of adrenaline and noradrenaline, thyroid hormones (Figueroa-Méndez \& Rivas, 2015). Depending on the environmental conditions and concentration, it can function as both an antioxidant and a prooxidant, which can stabilize the links of lipid peroxidation and antioxidant protection in patients with hypothyroidism.

Another way to prevent the process of oxidative stress is to use quercetin - a natural bioflavonoid extracted from Styphnolobium japonicum or Larix decidua wood (Haydarov, 2021). Due to its chemical structure, quercetin is the most active antioxidant among the known bioflavonoids and exerts its effect at all stages of the formation of reactive oxygen species and lipid peroxides (Makarenko, 2010).

Thus, the analysis of the current problem of pathogenesis of hypothyroidism theoretically substantiated the introduction of calcium, magnesium, vitamin $\mathrm{P}$ (quercetin) to the prophylactic complex, D, C, micronutrients selenium, copper, manganese to strengthen the antioxidant system, as an important component of metabolism, in the conditions of deficit of thyroid hormones.

In addition, the deficiency of macro-and micronutrients may be associated not only with insufficient supply to the body, but also with impaired absorption of relevant substances in the gastrointestinal tract, which occurs with functional decrease in the thyroid gland.

Therefore, the objectives of the present study were the condition of bone tissue and digestive tract in rats with hypothyroidism, as well as the effectiveness of preventive addition of a complex of drugs based on calcium citrate obtained from oyster shells, vitamins and minerals.

\section{Materials and methods}

The research was conducted in May-August 2020 at the Department of Human and Animal Physiology, Faculty of Biology, Odessa National University named after I. I. Mechnikov. Female laboratory rats of the Wistar line ( $165 \pm 23 \mathrm{~g}, 2.5$ months) were used in the work, which were kept in the standard vivarium conditions on a complete combined diet. Maintanance, feeding, care for the animals and withdrawal of the animals from the experiment were performed following the principles described in the Law of Ukraine "On Protection of Animals from Cruelty" (No. 1759-VI of 15.12.2009), taking into account the rules of the European Convention for the Protection of Vertebrate Animals Used for Experimental and Other Scientific Purposes (Strasburg, March 18, 1986, ETS No. 123).

The animals were divided into three groups. The first group was intact $(n=12)$ and served as a control. In rats of the second group $(n=8)$, the state of experimental hypothyroidism was simulated by oral administration of Mercazolyl drug (LLC "Pharmaceutical Company Health", Ukraine), the active substance of which is thiamazole. Mercazolyl refers to thyrostatics which blocks the activity of iodide peroxidase, and provide the most complete reproduction of the nature of morphological and functional disorders of the thyroid system (Vernigorodskyi et al., 2011). Rats of the third group $(\mathrm{n}=8)$, which had hypothyroidism simulated using Mercazolyl, received the complex of macro- and microelements, vitamins in the dose of $500 \mathrm{mg} / \mathrm{kg}$ added to the daily diet. Doses of components of the prophylactic complex (Table 1) are adequate daily amounts for humans, taking into account the relationship between body weight and surface area in humans and rats (Stefanov, 2001).

\section{Table 1}

The composition of the prophylactic complex based on calcium citrate

\begin{tabular}{lc}
\hline \multicolumn{1}{c}{ Component } & Quantity \\
\hline Selenium (Active Selenium, LLC Elite-Pharm, Ukraine), mg & 5.0 \\
Manganese (Active Manganese, LLC Elite-Pharm, Ukraine,), mg & 7.5 \\
Copper (Copper active, LLC Elite-Pharm, Ukraine), mg & 7.5 \\
Magnesium (Active Magnesium, LLC Elite-Pharm, Ukraine), mg & 5.0 \\
Calcium (calcium citrate from oyster shells) - a laboratory sample of its & 15 \\
own technology, mg & 5 \\
Ascorbic acid (Kyiv Vitamin Plant PJSC, Ukraine), mg & 3 \\
Vitamin D(Olidetrim Kids oral drops Medana Pharma JSC, Poland) IU & \\
Quercetin (Kvertin, 40 mg pills, Public Joint-Stock Company Research & 5 \\
and Production Center Borshchahiv Chemical-Pharmaceutical Plant, & \\
Ukraine), mg & 50 \\
Daily dose of the complex per 100 g of rat, mg
\end{tabular}

The duration of the experiment was 51 days. The rats were withdrawn from the experiment under thiopental anesthesia $(20 \mathrm{mg} / \mathrm{kg})$, predetermined body weight. The calculation of the organ index of the thyroid gland was carried out according to the formula: gland weight in $\mathrm{mg} / \mathrm{g}$ of body weight (Stefanov, 2001). To study the state of the skeletal system and gastrointestinal tract, we determined calcium content, indicators of inflammation (elastase activity, acid phosphatase), antioxidant-prooxidant status (catalase activity, glutathione reductase, malonic dialdehyde content), dysbiosis (activity of urease, and mucous membranes of the stomach, small and large intestine (Goryachkovsky, 2005; Levitsky et al., 2018).

Data in Tables and text are presented as mean \pm standard error $(\mathrm{x} \pm$ SE). The significance of the differences was assessed by ANOVA, P-values less than 0.05 were considered significant.

\section{Results}

First, it was shown that the introduction of mercazolyl for 51 days promoted increase in the organ index of the thyroid gland by $112.3 \%$ $(0.106 \pm 0.009$ and $0.225 \pm 0.017 \mathrm{mg} / \mathrm{g}$, respectively, $\mathrm{P}<0.001)$ in rats of the second group, indicating the formation of hypothyroidism in these animals. In rats of the third group, which received a complex of vitamins and minerals against the background of mercazolyl, the organ index of the thyroid gland corresponded to the level in intact animals and equaled $0.140 \pm 0.005 \mathrm{mg} / \mathrm{g}$. The obtained results indicate the high protective efficiency of the proposed complex of calcium citrate from oyster shell, 
magnesium, vitamins $\mathrm{P}$ (quercetin), D, C, trace elements $\mathrm{Cu}, \mathrm{Se}, \mathrm{Mn}$ in relation to the thyroid gland.

Therefore, to clarify the mechanisms of these disorders, as well as the effectiveness of the proposed scheme of their prophylaxis, it was advisable to conduct biochemical studies of bone destruction and osteogenesis (Table 2). Studies of the activity of bone enzymes in the jaws of rats found significant increase in the activity of two indicators that characterize bone destruction. Thus, the activity of elastase and acid phosphatase in the alveolar process increased by $68.3 \%(\mathrm{P}<0.01)$ and $46.4 \%(\mathrm{P}<0.001)$ respectively compared with animals in the control group. The obtained data indicate increase in inflammatory and destructive resorptive phenomena. The activity of alkaline phosphatase, a marker of bone formation, decreased by $11.0 \%(\mathrm{P}<0.05)$ compared with to the control (Table 2$)$.

In the bone tissue of the jaws of rats of third group, which received prophylaxis with vitamins and minerals against the background of modeling hypothyroidism, there was significant decrease in elastase activity by $26.2 \%(\mathrm{P}<0.05)$ compared with rats with hypothyroidism, and decrease in activity of acid phosphatase by $20.0 \%$ compared with the groups with pathology. These changes indicate decrease in inflammatory and destructive resorptive process in the bone tissue under the influence of the complex of calcium citrate preparations of oyster shells, $\mathrm{Mg}$, vitamins $\mathrm{P}$ (quercetin), $\mathrm{D}, \mathrm{C}$, trace elements $\mathrm{Cu}, \mathrm{Se}, \mathrm{Mn}$. Alkaline phosphatase activity in the bone tissue of the alveolar process of rats treated with a complex of drugs was $29.4 \%$ higher than in rats with hypothyroidism (Table 2). Increased activity of this enzyme indicates the activation of bone mineralization, which was somewhat reduced as a result of prolonged exposure to high doses of thyrostatics.

The level of ionized calcium in the alveolarprocess of rats with hypothyroidism and in prophylaxis against the background of modeling hypothyroidism was also determined (Table 2). In rats of the second group, we observed a significant $9.5 \%$ decrease in ionized calcium in the alveolar process compared with the control group of animals, which indicates signs of hydroxyapatite deficiency and the development of osteopenic condition. In the group of animals that received the prophylactic complex against the background of modeling hypothyroidism, the level of calcium in the bone tissue of the jaws corresponded to that of the control rats, even being $1.6 \%$ higher. Compared with the indicators of the second group of animals, in the third group we observed significant increase in calcium by $12.3 \%$ (Table 2).

\section{Table 2}

Indicators of remodeling in the alveolar process of rats with hypothyroidism after prophylaxis using the complex of minerals and vitamins ( $\mathrm{x} \pm \mathrm{SE}, \mathrm{n}=21$, duration of experiment -51 days)

\begin{tabular}{lccc}
\hline \multicolumn{1}{c}{ Indicator } & Intact group & $\begin{array}{c}\text { Hypo- } \\
\text { thyroidism }\end{array}$ & $\begin{array}{c}\text { Hypothyroidism }+ \\
\text { prevention }\end{array}$ \\
\hline $\begin{array}{l}\text { Elastase activity, } \mu \text {-cat/kg } \\
\text { Acid phosphatase activity, }\end{array}$ & $18.61 \pm 0.89$ & $31.31 \pm 1.55^{* *}$ & $23.09 \pm 0.76^{\#}$ \\
$\mu$-cat/kg & $2.74 \pm 0.22$ & $4.01 \pm 0.55^{* * *}$ & $3.21 \pm 0.43^{* *}$ \\
$\begin{array}{l}\text { Alkaline phosphatase activity, } \\
\mu \text {-cat/kg }\end{array}$ & $45.3 \pm 3.1$ & $40.3 \pm 4.3^{*}$ & $52.2 \pm 5.3^{*}$ \\
The content of ionized $\mathrm{Ca}^{2+}$ & $2.421 \pm 0.092$ & $2.191 \pm 0.080$ & $2.462 \pm 0.061$ \\
\hline
\end{tabular}

Note: $*-\mathrm{P}<0.05,{ }^{*}-\mathrm{P}<0.01,{ }^{* * *}-\mathrm{P}<0.001$ in comparison with the indicators of the intact group; ${ }^{\#}-\mathrm{P}<0.05$ compared with the hypothyroidism group.

Therefore, we can conclude the activation of inflammation and destruction, reducing the level of calcium in the bone tissue of animals with hypothyroidism. Prophylactic introduction of the proposed complex, which consisted of citrate from oysters, $\mathrm{Mg}$, vitamins $\mathrm{P}, \mathrm{D}, \mathrm{C}$, trace elements $\mathrm{Cu}, \mathrm{Se}, \mathrm{Mn}$, effectively prevented the development of destructive phenomena in the bone tissue of rats treated with mercazolyl for modeling hypothyroidism.

We analyzed the parameters of the antioxidant-prooxidant system of the bone tissue of the experimental animals. The content of malonic dialdehyde in the bone tissue of the jaws of rats with hypothyroidism increased by $31.5 \%$, indicating the strengthening of lipid peroxidation and the presence of oxidative stress in the bone tissue during experimental hypothyroidism (Table 3). Catalase activity in the second group was higher by $14.6 \%$, and the activity of this enzyme tended to increase, indicating the activation of antioxidant protection of the bone tissue in response to in- creased lipid peroxidation, induced by the development of hypothyroidism (Table 3).

\section{Table 3}

The state of some indicators of the antioxidant-prooxidant system in the bone tissue of the alveolar process of rats with hypothyroidism and after prophylaxis with the complex of vitamins and minerals $(\mathrm{x} \pm \mathrm{SE}, \mathrm{n}=21$, duration of experiment -51 days $)$

\begin{tabular}{lccc}
\hline \multicolumn{1}{c}{ Indicator } & Intact group & $\begin{array}{c}\text { Hypothy- } \\
\text { roidism }\end{array}$ & $\begin{array}{c}\text { Hypothyroidism }+ \\
\text { prophylaxis }\end{array}$ \\
\hline Malonic dialdehyde & $3.72 \pm 0.28$ & $4.89 \pm 0.31$ & $3.63 \pm 0.24$ \\
$\begin{array}{l}\text { content, mmol/kg } \\
\text { Catalase activity, } \mu \text {-cat } / \mathrm{kg}\end{array}$ & $2.05 \pm 0.16$ & $2.35 \pm 0.17$ & $2.13 \pm 0.14$ \\
$\begin{array}{l}\text { Glutathione reductase, } \\
\mu \mathrm{mol} / \mathrm{kg}\end{array}$ & $0.331 \pm 0.061$ & $0.485 \pm 0.062$ & $0.364 \pm 0.031^{*}$ \\
\hline
\end{tabular}

Note: see Table 2

The activity of the second antioxidant enzyme glutathione reductase in the bone tissue of the alveolar process increased by $46.5 \%$ in rats with hypothyroidism, which may indicate activation of the glutathione link of antioxidant protection as a compensatory response to the intensification of lipid peroxidation. The introduction of the prophylactic complex helped to prevent increase in the content of malonic dialdehyde and glutathione reductase activity in the bone tissue of the jaws of animals of third group. Catalase activity in the bone tissue of the jaws of rats with hypothyroidism and the addition of a prophylactic complex did not change significantly (Table 3). In turn, decreased calcium absorption in the small intestine of rats with hypothyroidism may be a consequence of disorders of the digestive tract. Therefore, we further studied the condition of various parts of the gastrointestinal tract of experimental animals using markers of inflammatory processes (elastase and acid phosphatase activity), the rate of contamination with opportunistic microbiota (urease activity), non-specific antimicrobial protection factor (prosontoid activity), systems (malonic dialdehyde content and catalase activity).

As shown in Table 4, the activity of elastase in the gums of rats with hypothyroidism increased by $49.5 \%$ compared with the intact group. The activity of the second marker of inflammation (acid phosphatase) in the gums of rats that received mercazolyl was also $21.0 \%$ higher than in the healthy animals $(\mathrm{P}<0.05)$. The obtained data indicate the presence of an inflammatory process in the oral cavity of animals with hypothyroiddism, which was caused by prolonged administration of mercazolyl. Along with the development of inflammation in the gums of rats against the background of hypothyroidism, the content of malonic dialdehyde increased by $44.4 \%(\mathrm{P}<0.05)$, indicating the activation of lipid peroxidation, as well as $45.8 \%(\mathrm{P}<0.001)$ increase in urease activity, suggesting increased contamination with opportunistic bacteria in the oral cavity of animals with hypothyroidism.

Modeling pathology of hypothyroidism did not significantly affect the indicators of nonspecific resistance-lysozyme and catalase, the activity of which underwent no significant changes compared with the gums in intact rats (Table 4).

The introduction of the prophylactic complex consisting calcium citrate from oyster shell, magnesium, quercetin, vitamins $\mathrm{D}, \mathrm{C}$, trace elements $\mathrm{Cu}, \mathrm{Se}, \mathrm{Mn}$, to the third group of rats effectively prevented the determined changes in the gums of animals with hypothyroidism. Thus, the activity of elastase in the gums of the third group of rats was $25.6 \%$ lower than in the second group $(\mathrm{P}<0.05)$ and corresponded to the values in healthy rats. Under the influence of the complex of drugs, the activity of acid phosphatase in the gums of rats decreased by $28.8 \%(\mathrm{P}<0.01)$. The results of the study of inflammatory markers indicate the anti-inflammatory effect of the prophylactic complex of vitamins and minerals in the development of hypothyroidism.

The introduction of the complex also prevented the increase in malonic dialdehyde in the gums of rats with hypothyroidism, the level of which in animals of the third group decreased by $30.3 \%$ compared with the second group and no significant difference with control was found. Along with the high level of catalase activity (18.6\% increase) in the gums of rats with hypothyroidism which received prophylaxis $(\mathrm{P}<0.05)$, there was decrease in malonic dialdehydelevels, which allows us to recommend using the set of drugs that can enhance antioxidant protection in the oral 
cavity against oxidative stress during the development of experimental hypothyroidism (Table 4).

\section{Table 4}

Biochemical parameters of the gums of rats with mercazolyl

hypothyroiddism and after using prophylactic complex

$(\mathrm{x} \pm \mathrm{SE}, \mathrm{n}=21$, duration of experiment -51 days)

\begin{tabular}{lccc}
\hline \multicolumn{1}{c}{ Indicator } & Intact group & $\begin{array}{c}\text { Hypo- } \\
\text { thyroidism }\end{array}$ & $\begin{array}{c}\text { Hypothyroidism } \\
+ \text { prevention }\end{array}$ \\
\hline Elastase activity, $\mu$-cat/kg & $92.3 \pm 6.6$ & $138.0 \pm 11.4^{*}$ & $109.8 \pm 8.4$ \\
Acid phosphatase activity, $\mu$-cat/kg & $25.4 \pm 1.2$ & $30.8 \pm 2.7^{* *}$ & $23.9 \pm 1.8^{*}$ \\
Malonic dialdehydecontent, & $25.8 \pm 1.9$ & $37.2 \pm 2.6^{*}$ & $28.5 \pm 2.1$ \\
mmol/kg & $0.481 \pm 0.032$ & $0.701 \pm 0.092^{* * *}$ & $0.531 \pm 0.042 \#$ \\
Urease activity, $\mu$-cat/kg & $95.2 \pm 7.1$ & $107.1 \pm 9.2$ & $132.1 \pm 11.2^{*}$ \\
Lysozyme activity, units/kg & $9.89 \pm 0.63$ & $8.64 \pm 0.79$ & $11.73 \pm 0.92^{*}$ \\
Catalase activity, mcat/kg & & &
\end{tabular}

Note: see Table 2.

Regular prophylactic administration of vitamins and minerals by rats with hypothyroidism also promoted decrease $24.3 \%(\mathrm{P}<0.05)$ in urease activity in the gums of animals, indicating the presence of antibacterial properties of the drug complex. Probably, the decrease in urease activity under the action of complex prophylaxis is a consequence of $23.4 \%$ ( $\mathrm{P}<$ 0.05 ) increase in lysozyme activity in the gums of animals that received the prophylactic complex with their diet. Therefore, the results of Table 4 show that experimental hypothyroidism leads to pathological disorders in the gums of rats, namely - the development of inflammation, increased membrane permeability, activation of lipid peroxidation and increased contamination with opportunistic bacteria. Prophylactic administration of the complex of calcium citrate from oyster shell, magnesium, quercetin, vitamins $\mathrm{D}, \mathrm{C}$, trace elements $\mathrm{Cu}$, Se, Mn effectively prevented the determined disorders due to the antioxidant, antibacterial and anti-inflammatory properties of the components of the prophylactic complex.

At the next stage, biochemical studies of the gastric mucosa of experimental animals were performed using the same parameters. The results of this analysis are shown in Table 5. As can be seen from these data, in the gastric mucosa of rats of second group, which received mercazolyl, elastase activity significantly increased by $24.3 \%$ compared with animals of the intact group, and the activity of lysosomal acid phosphatase increased by $35.3 \%(\mathrm{P}<0.05)$. This indicates the development of inflammatory processes in the gastric mucosa of animals against the background of hypothyroidism caused by mercazolyl.

\section{Table 5}

Biochemical parameters of the gastric mucosa of rats with mercazolyl hypothyroidism and after using the prophylactic complex $(\mathrm{x} \pm \mathrm{SE}, \mathrm{n}=21$, duration of experiment -51 days $)$

\begin{tabular}{lccc}
\hline \multicolumn{1}{c}{ Indicator } & Intact group & $\begin{array}{c}\text { Hypo- } \\
\text { thyroidism }\end{array}$ & $\begin{array}{c}\text { Hypothyroidism } \\
\text { + prevention }\end{array}$ \\
\hline Elastase activity, $\mu$-cat $/ \mathrm{kg}$ & $129.8 \pm 9.2$ & $161.4 \pm 12.0$ & $126.6 \pm 10.4$ \\
Acid phosphatase activity, $\mu$-cat/kg & $31.3 \pm 2.5$ & $42.4 \pm 3.8^{*}$ & $35.1 \pm 2.1$ \\
Malonic dialdehyde content, & $1.28 \pm 1.09$ & $16.19 \pm 1.12$ & $10.19 \pm 0.98$ \\
mmol/kg & $1.54 \pm 0.08$ & $2.01 \pm 0.16^{*}$ & $1.56 \pm 0.10$ \\
Urease activity, $\mu$-cat $/ \mathrm{kg}$ & $21.1 \pm 2.2$ & $9.1 \pm 1.1$ & $15.2 \pm 2.1$ \\
Lysozyme activity, units/kg & $4.11 \pm 0.25$ & $3.34 \pm 0.27$ & $4.20 \pm 0.19$ \\
Catalase activity, mcat/kg & & & \\
\hline
\end{tabular}

Note: see Table 2.

The increase in oxidative stress in the gastric mucosa of animals with hypothyroidism was evidenced by $21.9 \%$ increase in the content of malonic dialdehyde. At the same time, antioxidant protection in the stomach of rats with hypothyroidism decreased, as indicated by $18.7 \%$ decrease in catalase activity. The activity of urease in the gastric mucosa of the second group exceeded the activity of this indicator in the control group by $30.5 \%$ $(\mathrm{P}<0.05)$, suggesting the growth of opportunistic pathogens in this environment. In homogenates of the gastric mucosa of rats of second group, after administration of mercazolyl, we observed 2.3-fold decrease in lysozyme activity, indicating decrease in the level of nonspecific immunity of the gastric mucosa in animals with hypothyroidism (Table 5). Prophylactic administration of the complex by rats with hypothyroidism significantly reduced the level of both markers of inflammation in the gastric muco- sa: elastase decreased by $21.6 \%$ and acid phosphatase decreased by $17.1 \%$, and their activity indicators almost corresponded to normal values.

Due to the introduction of the prophylactic complex, in the gastric mucosa of animals of the third group, it was possible to significantly reduce the lipid peroxidation rate, which was $37.1 \%$ lower than in the group with hypothyroidism and $23.2 \%$ lower than in the first group. The introduction of the complex of drugs also effectively prevented the decrease in catalase activity in the gastric mucosa of animals with hypothyroidism. The activity of this enzyme in the group where the animals received prophylactic complex was lower than in the second group and almost equaled such in the control group (Table 5). Prophylaxis using the complex of vitamins and minerals had a positive effect on lysozyme, the activity of which in the gastric mucosa of animals of third group increased by $66.7 \%$, although it remained low compared with the intact group. Due to the increase in lysozyme activity in the gastric mucosa of rats of the third group, urease activity was normalized (Table 5).

Biochemical studies of the gastric mucosa of animals revealed the development of inflammation, activation of lipid peroxidation, increased contamination with opportunistic bacteria against the background of reduced antimicrobial and antioxidant protection of the mucous membrane in the presence of hypothyroidism caused by mercazolyl. Regular administration of the complex of vitamins and minerals by rats with hypothyroidism effectively prevented the determined disorders in the gastric mucosa.

The same indicators were determined in the mucous membrane of the small intestine. The results are shown in Table 6, indicating increase in inflammatory processes in the mucous membrane of the small intestine of rats with hypothyroidism, as evidenced by $37.6 \%(\mathrm{P}<0.05)$ increase in elastase activity compared with intact animals. The presence of inflammation in the mucous membrane of the small intestine of rats that received mercazolyl is also evidenced by $16.9 \%$ increase in acid phosphatase activity.

Along with the activation of inflammatory processes in the mucous membrane of the small intestine of rats with hypothyroidism, lipid peroxidation intensified, as indicated by 1.5-fold increase in the level of malonic dialdehyde $(\mathrm{P}<0.05)$. The development of hypothyroidism caused increased contamination with opportunistic microbiota on the mucous membrane of the small intestine, as urease activity in rats of the second group increased by $45.7 \%(\mathrm{P}<0.01)$. Against the background of activation of pathological processes in the mucous membrane of the small intestine of rats with hypothyroidism, we saw a significant inhibition of its antimicrobial function, as evidenced by 3.6-fold decrease in lysozyme activity and tendency towards reduction of antioxidant protection by reducing catalase activity by $15.6 \%$ (Table 6 ).

Regular introduction of the prophylactic complex based on vitamins and minerals to rats of the third group led to notable protective effect on the mucous membrane of the small intestine of rats with hypothyroidism. Thus, markers of inflammation in the mucous membrane of the small intestine of rats of third group decreased to the values of intact animals. After prophylaxis, urease activity in the small intestine also decreased to the level in intact rats. The introduction of the complex of drugs in rats with hypothyroidism very effectively prevented the decrease in lysozyme activity in the mucous membrane of the small intestine, which did not differ from normal values in animals of the intact group. Catalase activity after the introduction of the prophylactic complex was higher than the level of animals of the intact group $(\mathrm{P}<0.05)$. Due to the antioxidant properties of the prophylactic complex, the content of malonic dialdehyde in the mucous membrane of the small intestine of rats of third group decreased by 3.2 times compared with the level in second group $(\mathrm{P}<0.01)$ and the same time was 2.1 times lower than the values in intact group of rats (Table 6).

Thus, biochemical analysis of the mucous membrane of the small intestine of rats revealed induction of mercazolyl (development of hypothyroidism), the same pathological processes as in the tissues of the oral cavity and gastric mucosa: inflammation, oxidative stress, decreased antimicrobial protection and enhanced growth and reproduction. The introduction of the prophylactic complex of calcium citrate from oyster shell, magnesium, quercetin, vitamins $\mathrm{D}, \mathrm{C}$, trace elements $\mathrm{Cu}, \mathrm{Se}, \mathrm{Mn}$ effectively prevented the detected disorders in the mucous membrane of the small intestine of rats with hypothyroidism, exerting anti-inflammatory, antimicrobial and antioxidant effects. The results of the biochemical study of indicators in the mucous membrane of the colon of rats are presented in 
Table 7 and indicate the development of similar processes under the influence of hypothyroidism modeling by long-term administration of mercazolyl. This is, above all, the presence of inflammatory processes. The activity of elastase in the mucous membrane of the colon of rats with hypothyroidism was $29.3 \%$ higher than in the control group. The second marker of inflammation, the activity of acid phosphatase in the mucous membrane of the colon of rats with hypothyroidism also increased by $20.5 \%$ compared with the control values.

\section{Table 6}

Biochemical parameters of the small intestinal mucosa in rats with mercazolyl hypothyroidism and after using the prophylactic complex ( $\mathrm{x} \pm \mathrm{SE}, \mathrm{n}=21$, duration of experiment -51 days)

\begin{tabular}{lccc}
\hline \multicolumn{1}{c}{ Indicator } & Intact group & $\begin{array}{c}\text { Hypo- } \\
\text { thyroidism }\end{array}$ & $\begin{array}{c}\text { Hypothyroidism } \\
+ \text { prevention }\end{array}$ \\
\hline $\begin{array}{l}\text { Elastase activity, } \mu \text {-cat } / \mathrm{kg} \\
\text { Acid phosphatase activity, } \mu \text { - }\end{array}$ & $1.33 \pm 0.07$ & $1.83 \pm 0.12^{*}$ & $1.55 \pm 0.09$ \\
cat/kg & $46.3 \pm 3.2$ & $54.1 \pm 3.9$ & $45.52 \pm 2.8$ \\
$\begin{array}{l}\text { Malonic dialdehyde content, } \\
\text { mmol/kg }\end{array}$ & $2.74 \pm 0.16$ & $4.07 \pm 0.26^{*}$ & $1.28 \pm 0.10^{\#}$ \\
Urease activity, $\mu$-cat/kg & $1.27 \pm 0.08$ & $1.85 \pm 0.14^{* *}$ & $1.38 \pm 0.09$ \\
Lysozyme activity, units/kg & $51.1 \pm 6.2$ & $14.1 \pm 2.2$ & $49.1 \pm 5.2$ \\
Catalase activity, mcat/kg & $3.20 \pm 0.21$ & $2.70 \pm 0.19$ & $4.14 \pm 0.32^{*}$ \\
\hline
\end{tabular}

Note: see Table 2.

\section{Table 7}

Biochemical parameters of the mucous membrane of the colon of rats with mercazolyl hypothyroidism and after using prophylactic complex ( $\mathrm{x} \pm \mathrm{SE}, \mathrm{n}=21$, duration of experiment -51 days)

\begin{tabular}{lccc}
\hline \multicolumn{1}{c}{ Indicator } & Intact group & $\begin{array}{c}\text { Hypo- } \\
\text { thyroidism }\end{array}$ & $\begin{array}{c}\text { Hypothyroidism } \\
+ \text { prevention }\end{array}$ \\
\hline Elastase activity, $\mu$-cat/kg & $168.2 \pm 12.7$ & $217.4 \pm 13.5$ & $158.7 \pm 9.8$ \\
Acid phosphatase activity, $\mu$-cat $/ \mathrm{kg}$ & $28.4 \pm 2.1$ & $34.3 \pm 1.9$ & $28.9 \pm 2.1$ \\
Malonic dialdehyde content, $\mathrm{mmol} / \mathrm{kg}$ & $5.77 \pm 0.46$ & $8.55 \pm 0.63^{*}$ & $6.41 \pm 0.50$ \\
Urease activity, $\mu$-cat $/ \mathrm{kg}$ & $3.10 \pm 0.18$ & $3.80 \pm 0.24^{*}$ & $3.21 \pm 0.26$ \\
Lysozyme activity, units/kg & $40.1 \pm 3.1$ & $19.1 \pm 2.1^{* *}$ & $44.1 \pm 5.2$ \\
Catalase activity, mcat $/ \mathrm{kg}$ & $4.92 \pm 0.26$ & $4.38 \pm 0.39^{*}$ & $4.64 \pm 0.31$ \\
\hline
\end{tabular}

Note: see Table 2.

The intensification of lipid peroxidation in the mucous membrane of the colon of rats with simulated hypothyroidism manifested by $48.2 \%$ increase in the content of malonic dialdehyde $(\mathrm{P}<0.05)$ against a slight decrease in catalase activity (by $11.0 \%$ ). The development of hypothyroidism had a more significant effect on the antimicrobial function of the colon of rats, as the activity of lysozyme in its mucous membrane decreased by 2.1 times $(\mathrm{P}<0.001)$. Low lysozyme activity in this biotope led to $22.6 \%(\mathrm{P}<0.05)$ increase in urease activity, which means increased growth of opportunistic bacteria. Prophylactic administration of calcium citrate from oyster shell, magnesium, vitamins $\mathrm{P}, \mathrm{D}, \mathrm{C}$, trace elements $\mathrm{Cu}$, $\mathrm{Se}, \mathrm{Mn}$ prevented all the determined disorders in the mucous membrane of the colon caused by the development of hypothyroidism. Markers of inflammation (elastase and acid phosphatase activity), oxidative stress (malonic dialdehyde level), contamination with opportunistic bacteria (urease activity), as well as indicators of nonspecific resistance (lysozyme and catalase activity) in the mucous membrane of the colon in third group where the animals received the set of drugs corresponded to the normal values, i.e. values in intact animals (Table 7).

\section{Discussion}

Summary of the overall results of our experimental study. First of all, modeling of hypothyroidism in laboratory rats by long-term administration of the thyrostatic mercazolyl caused decrease in calcium levels and activation of destruction processes, both mineral (acid phosphatase activity) and organic component (elastase activity) of the bone tissue of animal jaws. In addition, in the bone tissue of the jaws of rats with hypothyroiddism, lipid peroxidation (malonic dialdehydecontent) intensified against the background of activation of antioxidant protection (glutathione reductase and catalase activity). Simulation of hypothyroidism with mercazolyl in laboratory rats led to increased activity of markers of bone resorption of acid phosphatase and elastase, increased lipid peroxidation and decreased calcium content in the alveolar process. Marker of osteogenesis, Hypothyroidism has not changed significantly. Preventive treatment of rats with hypothyroidism in the bone tissue of the jaws using the complex of minerals and vitamins led to decrease in the activity of elastase and acid phosphatase by $26.2 \%$ and $20.0 \%$, malonic dialdehyde - by $31.5 \%$ and increased alkaline phosphatase and calcium by $29.4 \%$ and $12.3 \%$ respectively, compared wwith the control. Activation of the antioxidant defense system in the bone tissue of the alveolar process of rats with hypothyroidism was evidenced by $31.5 \%$ increase in the content of malonic dialdehyde, $14.6 \%$ increase in catalase activity, $46.5 \%$ in glutathione reductase. The introduction of the prophylactic complex prevented oxidative stress against the background of enhanced processes of lipid peroxidation.

Studies of the biochemical parameters of the gums of rats with hypothyroidism revealed the presence of inflammatory processes: the activity of elastase increased by $49.5 \%$ compared with the intact group. Acid phosphatase activity in the gums of rats that were given mercazolyl was $21.0 \%$ higher than in healthy animals. In the group where the prophylactic complex was administered, decrease in inflammatory processes was recorded, as evidenced by decrease in elastase activity by $25.6 \%$ compared with the group with hypothyroidism, and acid phosphatase activity decreased by $28.8 \%$. Along with the development of inflammation in the gums of rats against the background of hypothyroidism, the malonic dialdehyde content increased by $44.4 \%$, indicating the activation of lipid peroxidation, as well as $45.8 \%$ increase in urease activity, suggesting increased contamination of the mouth cavity of animals with hypothyroidism with opportunistic bacteria. Therefore, experimental hypothyroidism caused by mercazolyl led to pathological changes in the bone tissue of laboratory rats. Studies have shown the activation of resorption, inflammation, peroxide processes in the bone tissue of rats with hypothyroidism, which may be associated with insufficient absorption of calcium and its low level in the blood. This assumption was confirmed by the study that revealed significant decrease in the intensity of calcium absorption, equaling $29.7 \%$ $(\mathrm{P}<0.01)$ in the mucous membrane of the small intestine of rats with hypothyroidism (Makarenko et al., 2021). The logical consequence of the deterioration of calcium absorption in rats with hypothyroidism is inevitably decrease in its level in the blood (Zaderei \& Makarenko, 2020), which triggers the mechanism of destruction of the bone tissue with the participation of parathyroid hormone.

In our opinion, the determined disorders in the bone tissue of rats with hypothyroidism may be the result of calcium deficiency as a result of its insufficient absorption in the small intestine, which was confirmed by the studies that found decrease in calcium absorption in the small intestinal mucosa of rats with hypothyroidism. The results of L. I. Sidorchuk \& A. S. Sidorchuk (2018) also suggest the development of intestinal absorption disorders in experimental animals with hypothyroidism due to reduced colonization resistance of the colonic mucosa, the development of dysbiosis, and contamination and colonization of the epithelial biofilm by mucosal microorganisms (Pacifici, 2021). Insufficient supply of calcium in the bloodstream after its absorption triggers the mechanism of bone resorption with the participation of parathyroid hormone (Cooney et al., 2021), as shown by our studies of bone tissue of rats with hypothyroidism Our assumption that the reason for the decrease in the absorption of calcium in the small intestine in hypothyroidism may be induced by mercazolyl pathological processes not only in the intestine but also in the entire digestive tract was confirmed by the biochemical studies of gums and gastric mucosa, small and large intestines. We found the development of oxidative stress, inflammatory and dysbiotic processes against the background of reduced antimicrobial and antioxidant protection in the mouth, stomach and intestines of animals with experimental hypothyroidism.

There are clinical studies of disorders of the digestive system in the conditions of hypothyroidism conducted by other authors: manifestations of loss of appetite, atrophy of the gastric mucosa, nausea, vomiting, dyskinesia of the colon, biliary tract, hepatomegaly in people with hypothyroidism (Schiellerup et al., 2019; Sorokman et al., 2019). Decreased motor function of the gastrointestinal tract is the most common sign of thyroid insufficiency (Balabolkin et al., 2007). Deficiency of thyroid hormones leads to decrease in intestinal motility, which can be clinically manifested by constipation, flatulence. During decrease in motility of a gastrointestinal 
tract, weakening of its motor function there is a stretching of the stomach and intestines that can lead to intestinal impassability. The secretory activity of the stomach is characterized by hypo- and achlorhydria with significant decrease in the content of pepsinogen in gastric juice (Tereshchenko, 2000). Hypothyroidism can directly affect the structure and the function of the liver. Inflammatory processes in the oral cavity of patients with hypothyroidism are characterized by high activity of inflammatory and destructive phenomena of the dental-maxillary joint. Low levels of calcium in the blood triggers the resorption of the bone tissue to overcome its deficiency and maintain a normal level of physiological processes that require a certain level of calcium in the blood (Fig. 1).

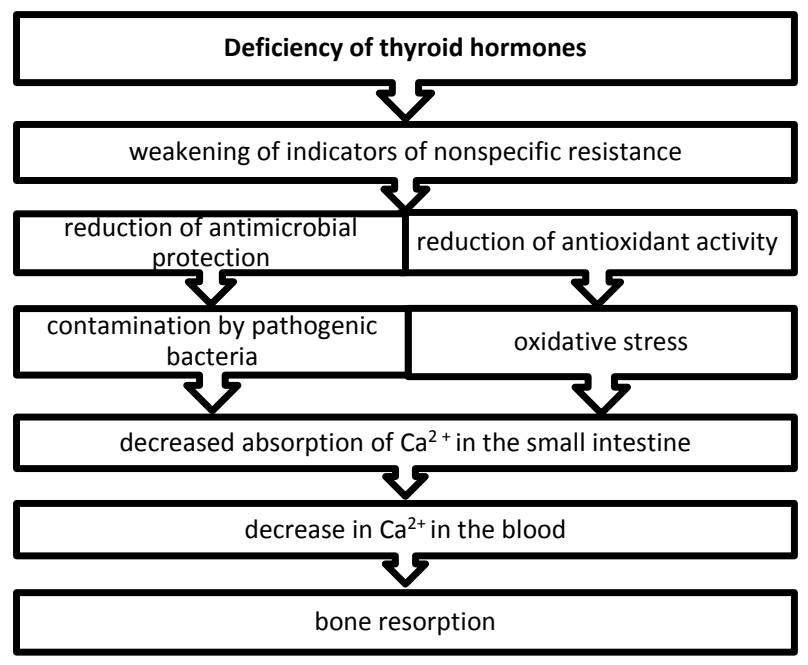

Fig. 1. Pathogenetic pattern of disorders in the digestive tract and bone tissue, caused by long-term use of mercazolyl

In our opinion, the initiator of all pathological changes in the digestive tract of animals after long-term administration of mercazolyl is the weakening of nonspecific resistance factors, namely antimicrobial protection with lysozyme and antioxidant system activity, including catalase, in the digestive tract. The consequences are the development of oxidative stress and increased growth of opportunistic bacteria in the gastrointestinal tract (Collins et al., 2017). In the future, this triggers a cascade of inflammatory reactions and the development of dysbiosis, the presence of which in the mucous membrane of the small intestine will inevitably inhibit the absorption of various substances, including calcium.

Prophylactic use of a complex preparation consisting of calcium citrate from oyster shells, magnesium, quercetin, vitamins D, C, trace elements $\mathrm{Cu}, \mathrm{Se}, \mathrm{Mn}$ in general had a positive effect on the normalization of the studied parameters in the oral cavity, gastric mucosa, various intestines and in the bone tissue of animals with simulated hypothyroidism.

\section{Conclusion}

Simulation of hypothyroidism in laboratory rats using mercazolyl led to increased activity of the markers of bone resorption of acid phosphatase and elastase, increased lipid peroxidation and decreased calcium content in the alveolar process. Marker of osteogenesis, hypothyroidism has not changed significantly. Prevention treatment of rats with hypothyroidism using the complex of minerals and vitamins decreased the activity of elastase and acid phosphatase by $26.2 \%$ and $20.0 \%$, malonic dialdehyde - by $31.5 \%$ and increased alkaline phosphatase and calcium by $29.4 \%$ and $12.3 \%$ respectively in the bone tissue of the jaws compared with the content of rats with hypothyroidism. Activation of the antioxidant defense system in the bone tissue of the alveolar process of rats with hypothyroiddism manifested in the increase in the content of malonic dialdehyde by $31.5 \%$, catalase activity by $14.6 \%$, glutathione reductase $-46.5 \%$. The introduction of the prophylactic complex prevented oxidative stress against the background of enhanced processes of lipid peroxidation.
Studies of the biochemical parameters of the gums of rats with hypothyroidism showed the presence of inflammatory processes: the activity of elastase increased by $49.5 \%$ compared with the intact group. Acid phosphatase activity in the gums of rats treated with mercazolyl was also $21.0 \%$ higher than in the healthy animals. In the group where the prophylactic complex was given, decrease in inflammatory processes was recorded, as evidenced by $25.6 \%$ decrease in elastase activity compared with the group with hypothyroidism, and $28.8 \%$ decrease in acid phosphatase activity. Along with the development of inflammation in the gums of rats against the background of hypothyroidism, the malonic dialdehydecontent increased by $44.4 \%$, indicating the activation of lipid peroxidation, as well as an increase in urease activity by $45.8 \%$, which indicates increased contamination of the mouth cavity of animals with hypothyroidism with opportunistic bacteria.

Studies of markers of inflammatory dysbacteriosis in different parts of the gastrointestinal tract (stomach, small and large intestine) revealed an increase in this indicator in the second group, and vice versa, reduced contamination by pathogenic microbiota, increased immune protection and reduced markers of oxidative stress in the group where the complex was administered.

According to the results of our research, the proposed complex of vitamins and minerals in hypothyroidism exerted antioxidant, anti-inflammatory and antidysbiotic efficacy in the tissues of the gums and mucous membranes of the gastrointestinal tract, thus normalizing the degree of calcium absorption in the small intestine and oxidative processes in the bone tissue of animals with hypothyroidism. Therefore, in general, prophylaxis using the complex of vitamins and minerals had a positive effect in the digestive tract and led to the normalization of the structural and functional state of bone tissue of rats with experimental hypothyroidism.

\section{References}

Ametov, A. S., \& Doskina, E. V. (2004). Zabolevaniya endokrinnoj sistemy i osteoporoz [Endocrine system diseases and osteoporosis]. Russkiy Meditsinskiy Zhurnal, 12(17), 1022-1028 (in Russian).

Asaiama, K., Dobashi, K., Khaiasibe, K., Mehata, Y., \& Kato, K. (1987). Lipid peroxidation and free radical scavengers in thyroid dysfunction in the rat: A possible mechanism of injury to heart and skeletal muscle in hyperthyroidism. Endocrinology, 121(6), 2112-2118.

Balabolkyn, M. Y., Klebanova, E. M., \& Kremynskaia, V. M. (2007). Fundamentalnaia y klynycheskaja tyreoydolohyia [Fundamental and clinical thyroidolgy]. Medytsyna, Moscow (in Russian).

Blomhoff, R. (2005). Dietary antioxidants and cardiovascular disease. Current Opinion in Lipidology, 16, 47-54.

Chukur, O. O., Pasiechko, N. V., \& Bob, A. O. (2020). Otsinka rivnia vitaminu D i yodnoho statusu $\mathrm{v}$ zhinok premenopauzalnoho viku z avtoimunnym zakhvoriuvanniam shchytopodibnoji zalozy [Evaluation of vitamin D levels and iodine status in premenopausal women with autoimmune diseases of the thyroid gland]. Zdobutky klinichnoji i Eksperymentalnoi Medytsyny, 44, 171-177 (in Ukrainian).

Collins, F. L., Schepper, J. D., Rios-Arce, N. D., Steury, M. D., Kang, H. J., Mallin, H., Schoenherr, D., Camfield, G., Chishti, S., McCabe, L. R., \& Parameswaran, N. (2017). Immunology of gut-bone signaling. Advances in Experimental Medicine and Biology, 1033, 59-94.

Cooney, O. D., Nagareddy, P. R., Murphy, A. J., \& Lee, M. (2021). Healthy gut, healthy bones: Targeting the gut microbiome to promote bone health. Frontiers in Endocrinology, 11, 620466.

Deluca, H. F. (2008). Evolution of our understanding of vitamin D. Nutrition Reviews, 66(10), 73-87.

Engler, H., Oettli, R. E., \& Riesen, W. F. (1999). Biochemical markers of bone turnover in patients with thyroid dysfunctions and in euthyroid controls: A crosssectional study. Clinica Chimica Acta, 289, 159-172.

Haydarov, S. T. (2021). Sravnitelnyj analiz antioksidantnoj aktivnosti kvertsetina i digidrokvertsetina pri eksperimentalnom gipotireoze [Comparative analysis of the antioxidant activity of quercetin and dihydroquercetin in experimental hypothyroidism]. Universum: Himiya i Biologiya, 82, 25-30 (in Russian).

Horiachkovskyi, A. M. (2005). Klinicheskaja biokhimija v laboratornoj diahnostike [Clinical biochemistry in laboratory diagnostics]. Ekologiya, Odessa (in Russian).

Hyrla, Y. V., Zhylyk, N. V., \& Muzyka, A. P. (2014). Nove v diahnostytsi funktsionalnoho stanu shchytopodibnoji zalozy [New in diagnostics of the functional state of the thyroid gland]. Khyst, 16, 343-348 (in Ukrainian). 
Jones, J. E., Desper, P. C., Shane, S. R., \& Flink, E. B. (1966). Magnesium metabolism in hyperthyroidism and hypothyroidism. The Journal of Clinical Investigation, 45(6), 891-900.

Karachentsev, Y. I., Goncharova, O. A., \& Ilina, I. M. (2014). Mikroelementnyj disbalans pri diffuzno-ochagovoj forme autoimmunnogo tireoidita [Trace element imbalance in diffuse focal form of autoimmune thyroiditis]. Mezhdunarodnyiy Endokrinologicheskiy Zhurnal, 61, 39-42 (in Russian).

Kivity, S., Agmon-Levin, N., Zisappl, M., Shapira, Y., Nagy, E. V., Dankó, K., Szekanecz, Z., Langevitz, P., \& Shoenfeld, Y. (2011). Vitamin D and autoimmune thyroid diseases. Cell Molecular Immunology, 3, 243-247.

Levytskyi, A. P., Makarenko, O. A., \& Demianenko, S. A. (2018). Metody eksperymentalnoj stomatolohiji [Experimental dentistry methods]. Tarpan, Symferopol (in Russian).

Mackawy, A. M., Al-Ayed, B. M., \& Al-Rashidi, B. M. (2013). Vitamin D deficiency and its association with thyroid disease. International Journal of Health Sciences, 7(3), 267-275.

Makarenko, O. A. (2010). Antyoksydantni mekhanizmy diji flavanojidiv u kistkovij tkanyni [Antioxidant mechanisms of action of flavonoids in bone tissue] Odeskyi Medychnyi Zhurnal, 121, 17-20 (in Ukrainian).

Makarenko, O. A., \& Zaderei, O. V. (2020). Kharakterystka biokhimichnykh ta morfometrychnykh pokaznykiv kistkovoji systemy pry eksperymentalnomu hipotyreozi [Characteristics of biochemical and morphometric parameters of the skeletal system in experimental hypothyroidism]. Colloquium Journal, 35, 38 41 (in Ukrainian).

Naidu, K. A. (2003). Vitamin C in human health and disease is still a mystery? Nutrition Journal, 2, 7-15.

Nochevnaya, L. B., Pavlenko, O. A., Kalinina, O. Y., \& Stolyarov, V. A. (2011). Sostoyanie kostnoy tkani u bolnykh s vpervye vyjavlennym gipotireozom [Bone tissue condition in patients with newly diagnosed hypothyroidism]. Sibirskiy Meditsinskiy Zhumal, 26(4), 189-193 (in Russian).

Pacifici, R. (2021). Role of gut microbiota in the skeletal response to PTH. The Joumal of Clinical Endocrinology and Metabolism, 106(3), 636-645.

Pankiv, V. I. (2014). Problema sochetannogo defitsita yoda i selena v razvitii zabolevanij schitovidnoj zhelezy [The problem of combined deficiency of iodine and selenium in the development of thyroid diseases]. Mezhdunarodnyiy Endokrinologicheskiy Zhurnal, 61, 75-80 (in Russian).

Rebrov, V. H., \& Hromova, O. A. (2003). Vitaminy ta mikroelementy [Vitamins and trace elements]. Alev-V, Moscow (in Russian).

Rustembekova, S. A., Ametov, A. S., \& Tliashinova, A. M. (2008). Elementnyj disbalans pri patologiji schitovidnoji zhelezy [Elemental imbalance in thyroid pathology]. Russkiy Meditsinskiy Zhurnal, 16, 1078-1080 (in Russian).
Schiellerup, S. P., Skov-Jeppesen, K., Windeløv, J. A., Svane, M. S., Holst, J. J., Hartmann, B., \& Rosenkilde, M. M. (2019). Gut hormones and their effect on bone metabolism. Potential drug therapies in future osteoporosis treatment. Frontiers in Endocrinology, 10, 75-90.

Soldin, O. P., \& Aschner, M. (2007). Effects of manganese on thyroid hormone homeostasis: Potential links. NeuroToxicology, 28(5), 951-956.

Sorokman, T. V., Khlunovska, L. I., Shvyhar, L. V., Andriichuk, D. R., \& Marchuk, Y. F. (2019). Zakhvoriuvannia orhaniv shlunkovo-kyshkovoho traktu pry suputnij patolohiji shchytopodibnoji zalozy (ohliad literatury) [Diseases of the gastrointestinal tract in concomitant pathology of the thyroid gland (review)]. Zdorovia Dytyny, 14, 52-59 (in Ukrainian).

Stefanov, O. V. (2001). Doklinichni doslidzhennia likarskykh zasobiv [Preclinical studies of medicinal plants]. Avitsena, Kyiv (in Ukrainian).

Sydorchuk, L. I., \& Sydorchuk, A. S. (2018). Kolonizatsijna rezystentnist slyzovoji obolonky tovstoji kyshky bilykh shchuriv z eksperymentalnym hipotyreozom [Colonization of resistant mucosa membrane of the large intestine rats with experimental hypothyroidism]. Mizhnarodnyj Endokrynologicnyj Zhurnal, 14(6), 636-641 (in Ukrainian).

Tamer, G., Arik, S., Tamer, I., \& Coksert, D. (2011). Relative vitamin D insufficiency in Hashimoto's thyroiditis. Thyroid, 21(8), 891-896.

Tereshchenko, Y. V. (2000). Patogenez, diagnostika i lechenie subklinicheskogo gipotireoza [Pathogenesis, diagnosis and treatment of subclinical hypothyroidism]. Klynycheskaia Medytsyna, 9, 8-12 (in Russian).

Timirhanova, G. A., Abdullina, G. M., \& Kulagina, I. G. (2007). Vitamin C: Klassicheskie predstavlenija i novye fakty o mehanizmah biologicheskogo dejstvija [Vitamin C: Classic concepts and new facts about the mechanisms of biological action]. Vyatskiy Meditsinskiy Vestnik, 4, 158-161 (in Russian).

Tutel'yan, V. A., Knyazhev, V. A., \& Khotimchenko, S. A. (2002). Selen v organizme cheloveka: Metabolizm, antioksidantnye svoystva, rol' v kantserogeneze [Selenium in the human body: metabolism, antioxidant properties, role in carcinogenesis]. RAMN, Moscow (in Russian).

Verma, S., Kumar, P., Laloraya, M., Nivsarkar, M., \& Singh, A. (1991). Superoxide dismutase activation in thyroid and suppression in adrenal. Novel pituitary regulatory routes. FEBS Letters, 282(2), 310-312.

Vernyhorodskyi, V. S., Fetisova, N. M., \& Vernyhorodska, M. V. (2011). Adaptatsijnyj potentsial i reabilitatsijnyj prohnoz u khvorykh na hipotyreoz [Adaptation potential and rehabilitation prognosis in patients with hypothyroidism]. Endokrynolohijia ta Endokrynna Khirurhiia, 2, 34-36 (in Ukrainian).

Zaderei, O. V., \& Makarenko, O. A. (2020). Biokhimichni pokaznyky syrovatky krovi ta pechinky shchuriv pry eksperymentalnomu hipotyreozi [Biochemical indicators of blood serum and liver of rats with experimental hypothyroidism]. Visnyk Morskoji Medytsyny, 89, 98-102 (in Ukrainian). 